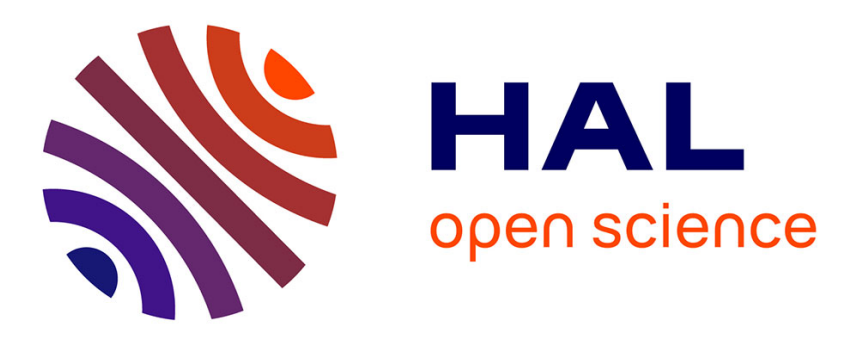

\title{
Technical Study and Conservation - Treatment of a Horse Model by Dr Auzoux
}

\author{
Barbara Dumont, Anne-Laurence Dupont, Marie-Christine Papillon, \\ Gaël-François Jeannel
}

\section{- To cite this version:}

Barbara Dumont, Anne-Laurence Dupont, Marie-Christine Papillon, Gaël-François Jeannel. Technical Study and Conservation - Treatment of a Horse Model by Dr Auzoux. Studies in Conservation, 2011, 56, pp.58 - 74. 10.1179/sic.2011.56.1.58 . hal-01491175

\section{HAL Id: hal-01491175 \\ https://hal.science/hal-01491175}

Submitted on 22 Mar 2017

HAL is a multi-disciplinary open access archive for the deposit and dissemination of scientific research documents, whether they are published or not. The documents may come from teaching and research institutions in France or abroad, or from public or private research centers.
L'archive ouverte pluridisciplinaire HAL, est destinée au dépôt et à la diffusion de documents scientifiques de niveau recherche, publiés ou non, émanant des établissements d'enseignement et de recherche français ou étrangers, des laboratoires publics ou privés. 
RESEARCH PAPER

\title{
Technical Study and Conservation Treatment of a Horse Model by Dr Auzoux
}

\author{
Barbara Dumont, Anne-Laurence Dupont, Marie-Christine Papillon and \\ Gaël-François Jeannel
}

This paper reports on technical investigations and conservation work carried out on a papier mâché anatomical model of a horse created in the mid-nineteenth century by Dr Auzoux. The object suffered from a structural unbalance due to the distortion of the internal metal structure, and its painted surface exhibited severe flaking. The treatments mainly entailed surface cleaning and consolidation of the paint layers. A gelatine with a good adhesive power and a high gel strength was chosen as a consolidant. The method developed proved very effective and could be applied in the future on other deteriorated Auzoux models. In order to better understand the flaking process, mock-ups of painted surfaces were prepared and were artificially aged under cycling heat and humidity. This experimental work showed the importance of maintaining optimal and stable climatic conditions for the storage of the model. A scientific examination of the techniques and materials involved in the fabrication of the horse was conducted using historic sources as well as analytical investigation. The findings confirmed previous data published on Auzoux models. It also unveiled further information not reported to date as this type of research on such a large Auzoux model had never been carried out before.

\section{INTRODUCTION}

Auzoux models are spread over several collections worldwide. With recent new interest in their high scientific value and their incredible quality of craftsmanship, scientific examination and conservation studies are much needed in order to better understand these objects and the stability of their materials in climatic variations. This study of the anatomical model of a horse that Auzoux created circa 1850 is to the authors' knowledge the first of this kind. It gathers a complete set of scientific data and information obtained using various experimental, analytical and historical approaches. The emphasis is placed on the technical study and the surface conservation treatment. When the horse arrived in the laboratory, the internal structure was distorted, which made it lean slightly to one side, and the painted surface was flaking extensively. The aim of the treatment was to improve the condition and the appearance of the object on permanent display in the museum of the national veterinary school of Maisons-Alfort (Musée Fragonard). The treatment

Received July 2010 was mainly dedicated to surface cleaning and to the consolidation of the paint layers using gelatine. Besides the practical conservation work, which was extremely painstaking, a detailed scientific examination of the techniques and materials involved in the fabrication of the Auzoux horse was conducted. Available historic sources were compared to the results obtained with various analytical techniques such as scanning electron microscopy with energy dispersive X-ray spectrometry (SEM-EDX), Raman spectroscopy and gas chromatography coupled to mass spectrometry (GC-MS). The experimental work also involved the fabrication of paint mock-ups, which after artificial ageing displayed a flaking surface very similar to that of the object. The use of mock-ups led to a better understanding of the cause of the degradation observed on the paint layers of the object.

\section{TECHNICAL STUDY}

\section{History and description of the object}

Louis Thomas Jerôme Auzoux (1797-1880) was a French physician who invented a production method 
for papier mâché anatomical models at a time when anatomic dissections for teaching purposes were difficult to perform due to the lack of refrigeration techniques. He first made human models and, as he witnessed comparative anatomy developing into a scientific discipline, he also manufactured animal models [1]. The first horse model he produced was ordered by the ministry of war at a time when horses were essential in daily life, not only for military purposes, but also for farming and transportation [2]. This anatomical Auzoux model is an exceptional artefact as only a few horses were manufactured. As far as we know there are about six other horses belonging to scientific collections worldwide (Lyon, Madrid, London, Halle and New Delhi).

Dr Auzoux invented clastic anatomy. The word 'clastic' arises from the Greek word klao and means 'taking apart'. The anatomical models are composed of parts that can be put together and taken apart as in an actual anatomic dissection. Small paper labels stuck on the painted surface identify the different body elements. Small hands and corresponding numbers, also printed on paper, refer to a synoptic table that indicates the order for the dismantlement [3].

The French doctor had a very good knowledge of the new techniques from the emerging papermaking industry, and worked with cartonniers (carton, or 'papier mâché craftmen'), carpenters, sculptors and painters. His first models of the human body were shown to the Académie royale de médecine in 1822 and were immediately praised by the intellectual community. $\mathrm{He}$ was only 25 when he opened a factory in his birthplace of Saint Aubin d'Ecrosville, in Normandy [4] and began to sell his creations to universities and to schools all over the world. The Musée de l'écorché du Neubourg, which opened nearby in 1995, is dedicated to Dr Auzoux's inventions. A large body of information on the materials and techniques used in Auzoux's production can be found at the museum. Indeed, old tools and moulds, as well as earlier anatomical models, are displayed.

After its manufacture between 1855 and 1860, the horse model moved to Alfort where it stayed until it went to the National School of Agronomy in Grignon, near Paris, in 1871. In the early 1990s, it was shipped back to Maisons-Alfort, and in 2003 joined the museum collections.

The model bears neither signature nor date, as opposed to most Auzoux models conceived at that time [5]. The materials of the horse are papier mâché, metal, wood, plant fibres and fish glue. It weighs 65 kilograms and its dimensions are $158.5 \mathrm{~cm} \times 167 \mathrm{~cm} \times 50 \mathrm{~cm}$.

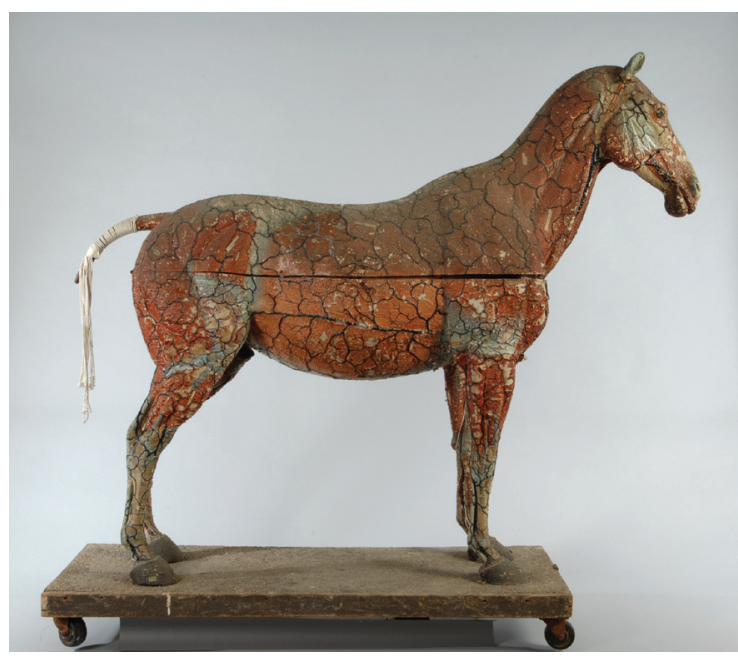

(a)

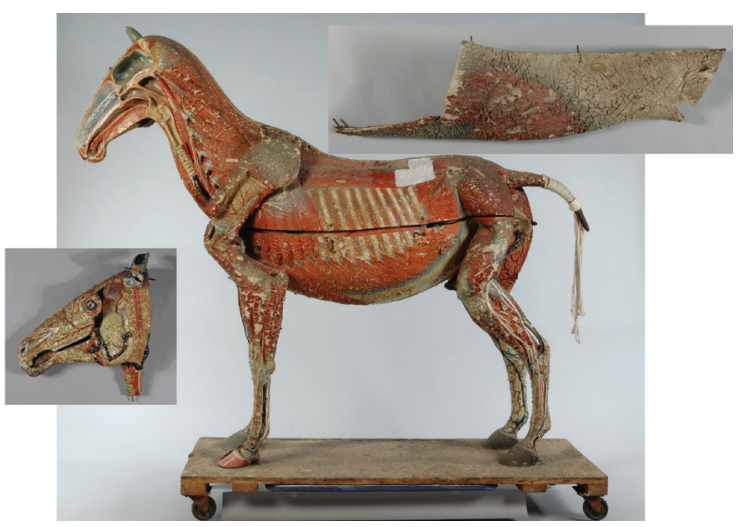

(b)

Figure 1 Photographs showing lateral views of the horse before treatment: (a) right; and (b) left. @ G. Inp / Vanneste.

The horse is reproduced at a $75 \%$ scale. It has several movable and removable parts. The exterior of the object reveals the animal's muscle structure. On the right side of the horse, the vascular network is visible (Figure 1a). The left side, which shows the inner muscle structure, has two movable elements that can be pulled apart from the body: the half head and the superficial back muscle (Figure 1b).

The left thoracic limb can also be taken apart (Figure 2a). It then becomes possible to open the horse from head to tail like a box. The 'cover' part can be lifted like a lid and is articulated on metal hinges located at the back near the tail of the animal (Figure 2b). When open, the horse stands on three limbs. This would explain 


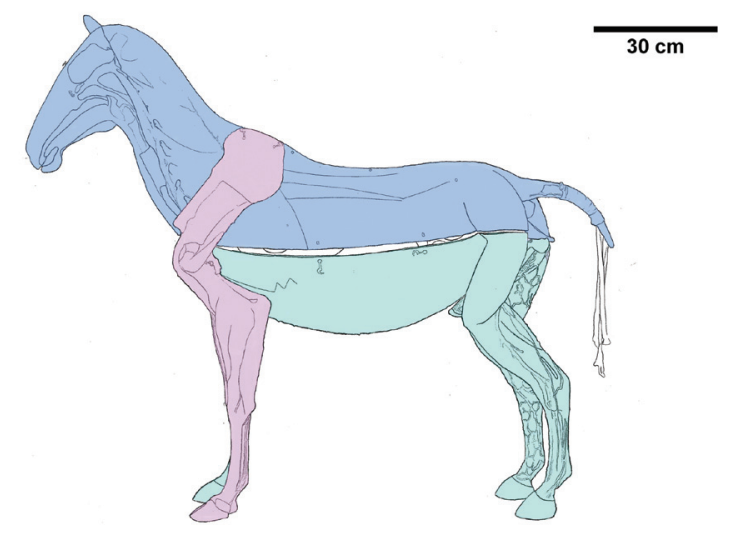

(a)

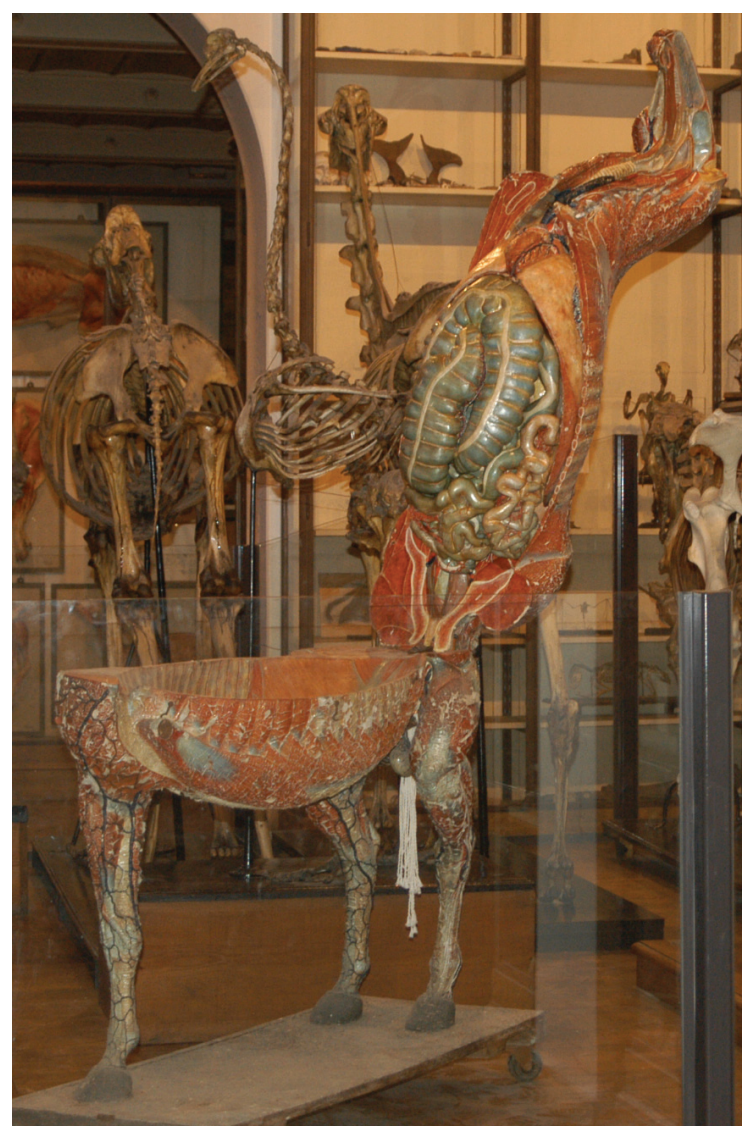

(b)

Figure 2 (a) Scheme of the horse showing the location and shape of the left thoracic limb (C) Inp / B. Dumont); and (b) photograph of the model open as it was presented at the Musée Fragonard before treatment (C C. Degueurce). the structural problem if the horse had been displayed open for prolonged periods. The interior organs are held inside the upper part of the body with hooks and eyes and can be disassembled. The colours are bright and shiny and mimic the animal flesh and organs with amazingly realistic details. The superimposed paint layers that provide such a vivid rendering are extremely elaborate. This is described in the subsection on Ground and paint layers.

\section{Composition of the object}

Auzoux models are usually described as being made of papier mâché. However, it is worth pointing out that the French term papier mâché refers to both carton pâte or carton collé techniques; in Italian, cartapesta or cartone, and in English, paper pulp or cardboard. In other words, carton pâte can be the equivalent of paper pulp or cartapesta.

It is important to clarify this vocabulary as Auzoux used two distinct techniques to build his anatomical models depending on whether the parts were designed to be light and removable, or more robust such as those needed for holding the structure in place. Light elements were made of strips of paper assembled together with glue while still wet, a technique called papier collé [6]. Several layers - up to twelve - of small strips of torn paper impregnated with starch glue were laid in a plaster mould. They were sewn together with an iron thread. The resulting element was hollow (Figure 3a).

The pieces which had a structural function (robust parts) were made by filling up moulds with the specific paper pulp called carton pâte (Figure 3b). Auzoux named it terre, which means 'earth' or 'clay'. He kept the ingredients and the recipe secret. When dry, the parts were described as being as hard as wood. These structural elements are filled parts; they are the upper part, the lower part and the left thoracic limb. The moulding was carried out in heavy metal moulds held in wooden frames (Figure 4a) that allowed reproduction of the same pieces several times, i.e. in small-scale serial production. The manufacturing of these metal moulds was Auzoux's invention. A technique of casting was used. In this ingenious process, carton collé pieces were used as core pieces (Figure 4b). The alloy used, invented by a chemist named Jean Darcet (1725-1801), was made of lead, antimony and tin. Because of its low melting point, the molten metal did not burn the paper nor the wood when it was poured into the wooden frames holding a core (Figure $4 \mathrm{~b}$ ). The paper pulp was hammered down into the three-dimensional finely structured lead- 


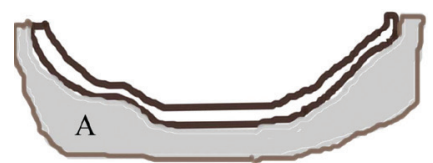

Plaster mould made of two shells $\mathrm{A}$ and $\mathrm{B}$

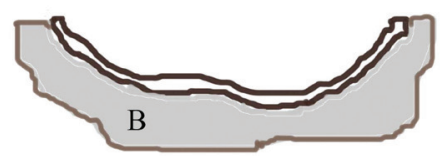

Cartons collés are made in the shells

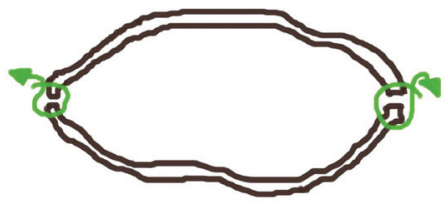

Sewing of the two pieces together

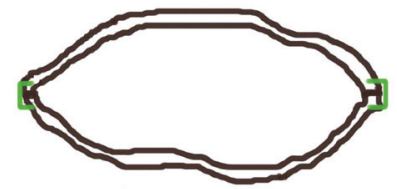

Hollow carton collé

(a)

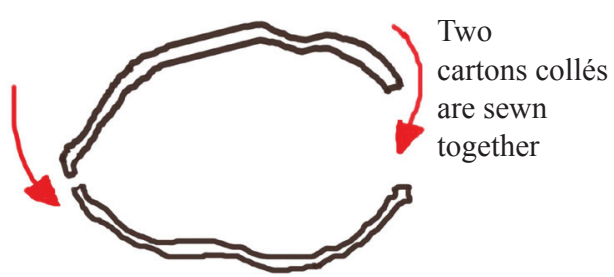

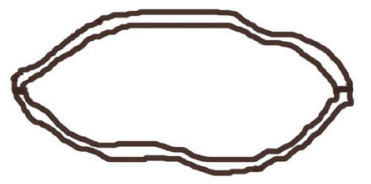

Hollow carton collé

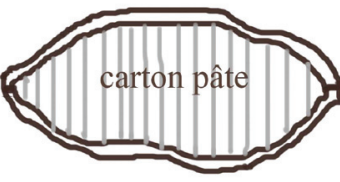

Full carton collé (b)

Figure 3 Schemes of the making of cartons collés: (a) technique of fabrication in a plaster mould; and (b) empty and filled body parts. (C Inp / B. Dumont)

antimony-tin moulds. A metal armature was added, as shown by X-radiography (see section on Scientific Examination of the Object). The mould was finally closed and placed in a cider press, where the materials

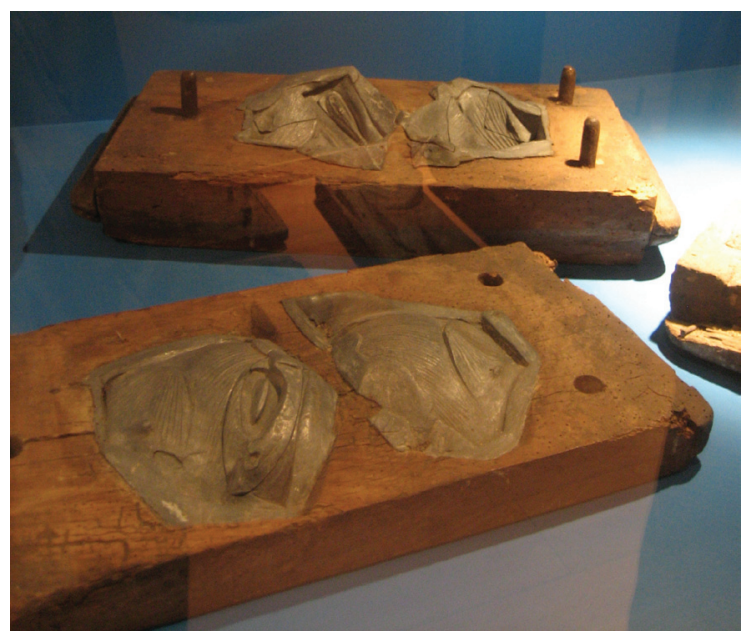

(a)

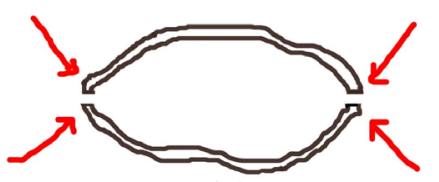

Two carton collés make a core

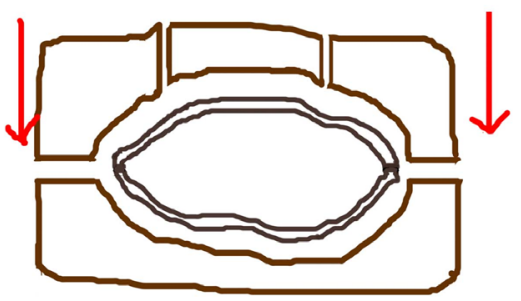

The core is placed between the frames

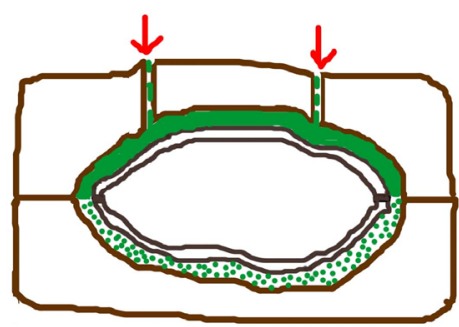

The alloy fills the space between (b)

Figure 4 (a) Photograph of the metal moulds laid in their wooden frames (Musée de l'écorché du Neubourg, (C) B. Dumont); and (b) scheme of the technique of casting used to manufacture the metal moulds held in wooden frames (C Inp / B. Dumont). 


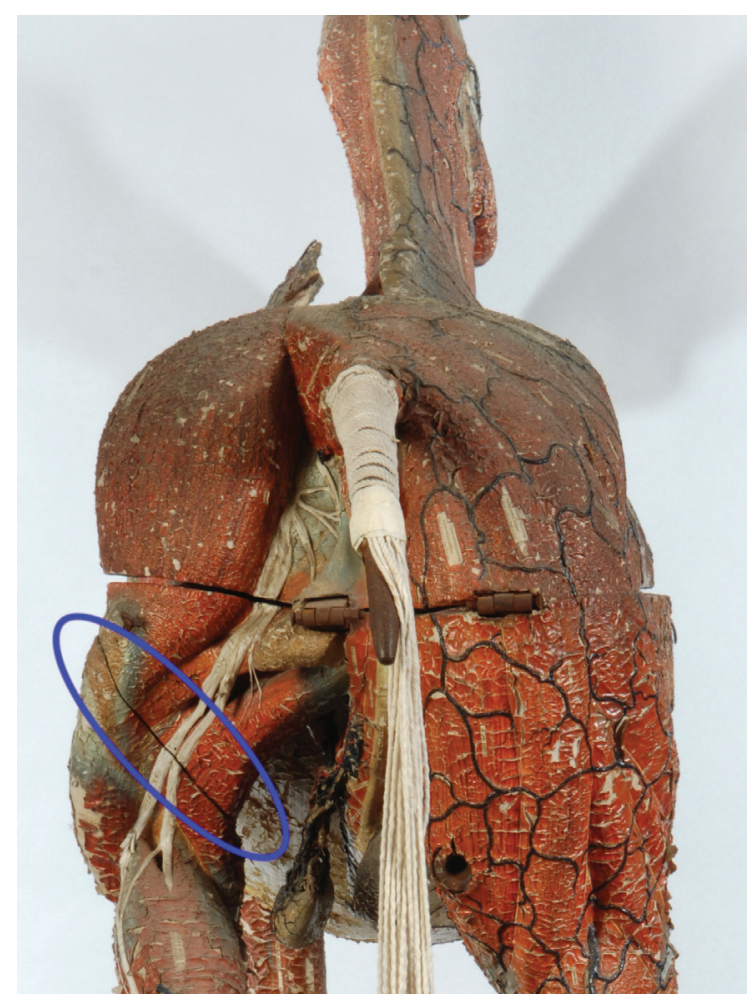

(a)

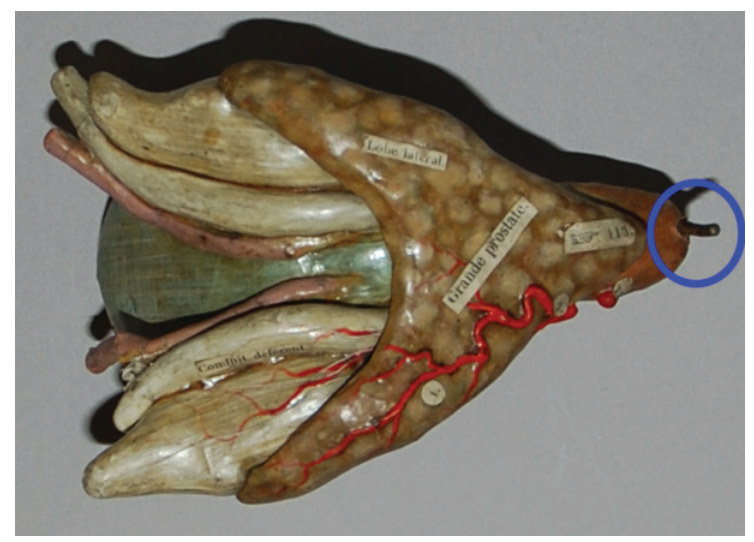

(b)

Figure 5 Photographs of details of the model: (a) joint area of the left back limb; and (b) back of the bladder with metal rod. ( ) Inp / B. Dumont.

were allowed to dry. Later, the pieces were refined and assembled. The joint area is visible on the object, for example on the back limb (Figure 5a).
The pieces were covered with a thin layer of paper that was intended to hide the small imperfections, and to obtain a smooth surface for the paint layers. This procedure was called rapapillotage. On the horse model, the rapapillotage paper is visible in the paint lacunae. The elements were then assembled with hooks and eyes, hinges and metal rods. This is visible at the back of the horse's bladder, a $15 \mathrm{~cm}$-long removable piece (Figure $5 \mathrm{~b}$ ).

Finally, the paint layers were applied. The process required four stages: making the vessels, painting, labelling and applying a protective coating to the surface. The vessels were made with metal threads, mainly iron, which were prepared separately and were covered with plant fibres. A morphological examination of these fibres with an optical microscope showed that they are ramie fibres. The vessels were then applied on the paper surface and nailed onto the model (Figure 6). They are mostly present on the right side of the body, which shows the vascular network (Figure 1a).

The painting process consisted of the superimposition of several pigmented layers. The upper layer was not pigmented and had a protective function. According to the information gathered at the Musée de l'écorché du Neubourg, the binding media was sturgeon glue. Russian fish glue, which at the time was a very expensive material, is mentioned at the museum. The entire technique of manufacturing the anatomical models is particularly informative with respect to Auzoux's knowledge of materials. For instance, wax, besides being very expensive at the time, would not have allowed for easy handling and dismantling of the object, while wood would have not allowed for high precision in the rendering of the reliefs. The use of paper materials

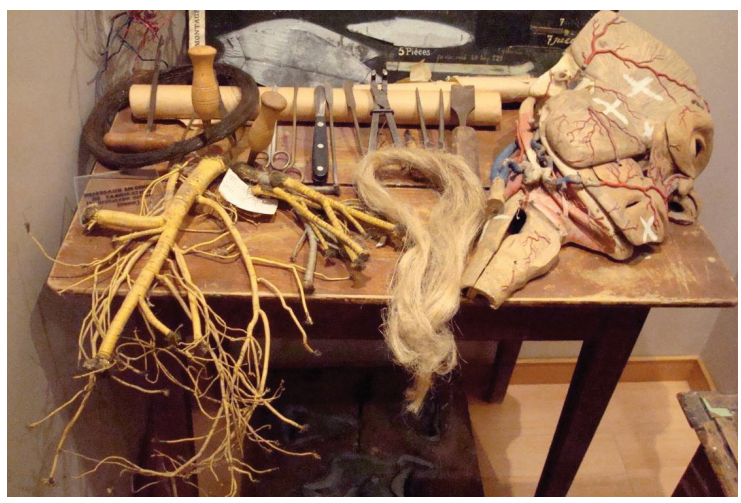

Figure 6 Photograph of a display at Musée de l'écorché du Neubourg showing the tools and materials used for making the vessels. (C) B. Dumont. 
and the sophisticated paint application technique were the ideal solution for obtaining a structure with similar properties as a wooden material, and at the same time an impressive visual appearance of translucency of the surface paint as if it were a wax model.

\section{SCIENTIFIC EXAMINATION OF THE OBJECT}

\section{Structural elements}

Visual examination was done with a binocular microscope. X-radiography, as reported by Barden [7] and Karlson [8], allowed examination of the internal structure of the large model and revealed the location, shape and size of the armatures as well as the construction method of the veins and the arteries (Figure 7a). The $\mathrm{X}$-radiography was used with the following parameters: $5 \mathrm{~mA}$ and 40 to $80 \mathrm{kV}$ with an exposure time of 1 to 2 minutes. It shows that the model is built on a complex iron frame. This frame is enclosed in the paper pulp as described earlier. In some parts of the body the density of metal elements is very high (Figure 7b) and the armature is difficult to understand, whereas the structural elements of the limbs are very clear (Figure 7c).

\section{Components of organic origin}

The paper fibres were examined with an optical microscope after staining with Herzberg stain [9] and were identified as textile fibres (linen and/or hemp as well as cotton). The paint lacunae were large enough to see the paper underlayer. However, it was not possible to determine whether the paper was handmade or industrially made as no texture was visible. The organic components such as the glue used in the carton pate and the carton colle, the binding media of the painting and the protective coating of the paint layer were analysed using GC-MS. The details of the analytical procedure can be found in the Appendix. Starch was identified based on the presence of glucose, and it was concluded that flour was probably used to make the starch-based glue.

The GC-MS analysis also identified collagen as the binding media. The origin of the collagen could be from mammals or from fish. The use of sturgeon glue cannot be confirmed with this technique. Unfortunately, throughout the nineteenth century, falsifications of sturgeon gelatine seemed commonplace [10].

Ground cork and calcium carbonate, probably chalk, were identified in the paper pulp (carton pâte) using SEM-EDX (details of the analytical procedure are in the Appendix) (Figure 8). This is consistent with the information available from the Musée de l'écorché du Neubourg. These materials were used together with the ramie fibres, starch paste and strips of paper. However, no information could be obtained on the respective proportion of these compounds. Moreover, the addition of ground cork, which was not habitually used by cartonniers throughout the nineteenth century [11], was kept secret during Auzoux's lifetime.

\section{Ground and paint layers}

Because the study had conservation purposes, it was possible to take only a few samples from the object. Five of them were prepared as cross-sections, after embedding in a polyester resin, with the aim of understanding the painting techniques and identifying the pigments and extenders used to make the polychromy. The cross-sections were first observed using polarized light microscopy (PLM) and fluorescence microscopy (FM).A variable pressure scanning electron microscope (VPSEM) was then used to examine the samples. Elemental analysis was conducted by EDX. This microanalytical technique is qualitative and sensitive for all elements but it does not allow the organic compounds to be identified. The list of the samples, sampling locations and the results are summarized in Table 1. Details of the equipment and the analytical parameters are reported in the Appendix.

Whereas wax models are made of pigmented materials $[12,13]$, the bright glossy colours observed on the horse are the result of polychrome work (Figure 9) composed of a ground layer covered with numerous layers, which are either glazed or coloured with pigments and protected by a thick translucent surface coating (up to $20 \mu \mathrm{m}$ thick). The stratigraphy consists of an organic underlayer applied to the rapapillotage paper, covered by one or two layers of a white ground made of lead white (except for the sample Auz-03, black hoof). The total thickness of the ground is irregular, from 10 to $60 \mu \mathrm{m}$ thick, and is characterized by a homogeneous grinding and medium size particles (average diameter 1-3 $\mu \mathrm{m}$, with large agglomerates). When details were applied on the surface, such as a blue vein on the red muscles or white nerves on the yellowish underbelly, an extra thin layer of lead white $(3-10 \mu \mathrm{m}$ thick) was applied as a ground. For the samples from the red and blue parts of the horse, a glazed layer was first laid down on the ground whereas pigmented layers were applied in the yellow areas (sample AUZ-05) and on the horn (AUZ-03). The white ground does not exist in the horn sample; the first coloured layer was applied directly on the organic underlayer and only four glazed layers were 

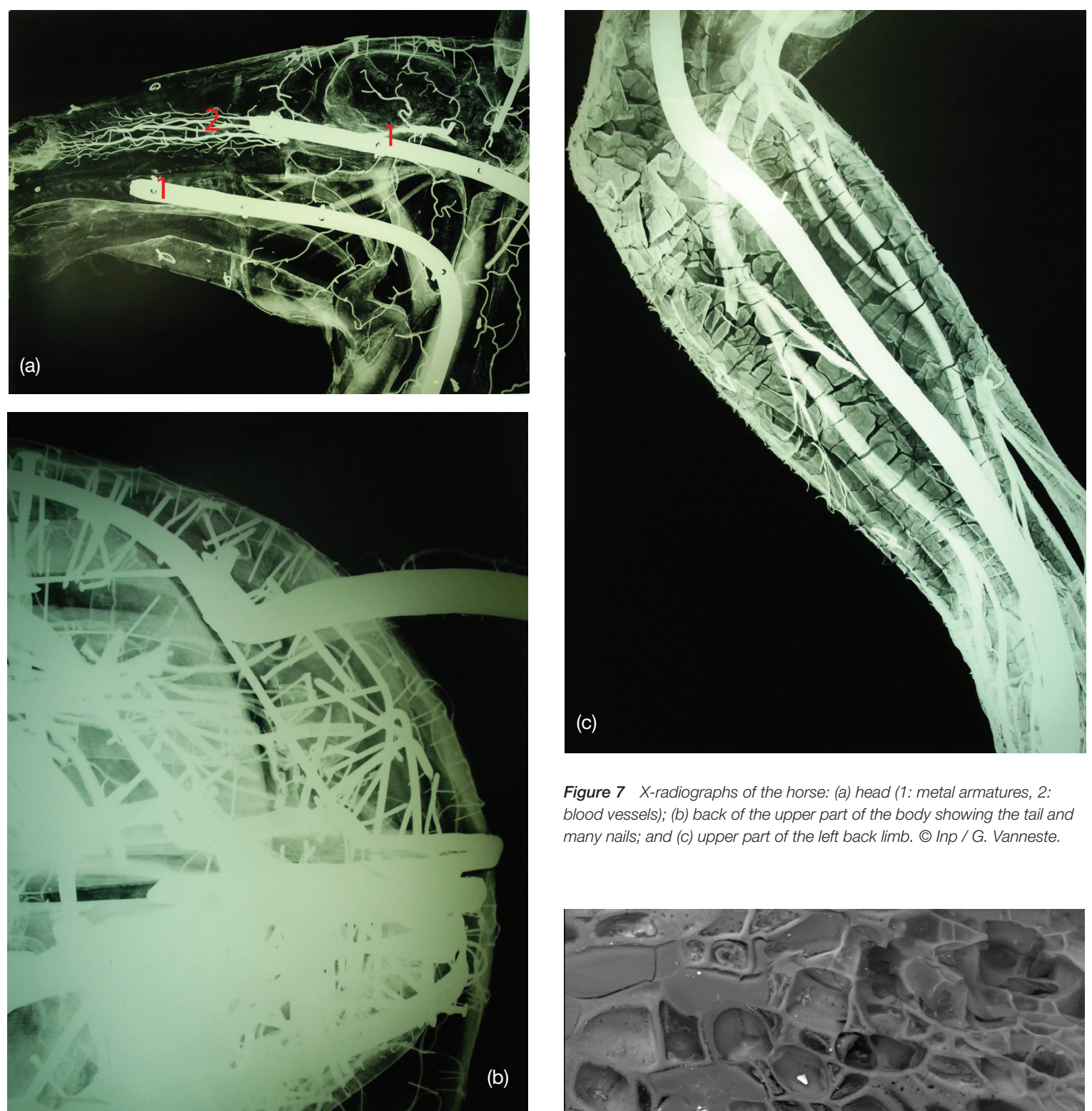

Figure $7 \quad X$-radiographs of the horse: (a) head (1: metal armatures, 2: blood vessels); (b) back of the upper part of the body showing the tail and many nails; and (c) upper part of the left back limb. (C) Inp / G. Vanneste.

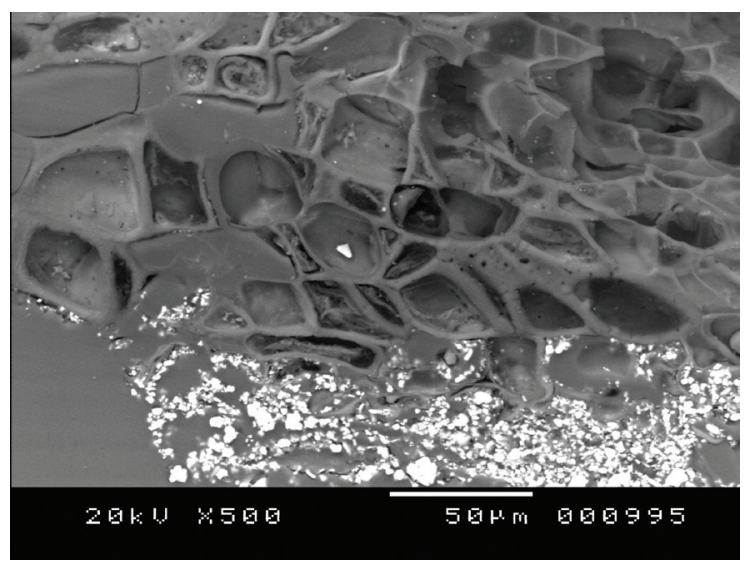

superimposed. Except for the layers directly applied on the ground (up to $40-50 \mu \mathrm{m}$ ), the pigmented layers were thin, often around micrometric thickness, and one single line of particles can be observed. These pigmented layers are held between thicker glazed layers (around 40 or $50 \mu \mathrm{m}$ ) which contain small amounts of various pigments or white extenders, sparsely mixed with the binding material.

Figure 8 Back-scattered electron micrograph of a cross-section of the paper pulp (sampled in left hip) showing polygonal cells which were identified as cork cells. @ Inp / M.-C. Papillon. 
Table 1 Summary of the microscopic observations and results of the elemental analysis

\begin{tabular}{|c|c|c|c|c|c|c|c|}
\hline & \multirow[t]{2}{*}{ Auz-01 } & \multicolumn{2}{|c|}{ Auz-02 } & \multirow[t]{2}{*}{ Auz-03 } & \multirow[t]{2}{*}{ Auz-04 } & \multicolumn{2}{|c|}{ Auz-05 } \\
\hline & & lower layers & upper layers & & & lower layers & upper layers \\
\hline Location & left posterior limb & \multicolumn{2}{|c|}{ left anterior limb } & $\begin{array}{l}\text { right anterior } \\
\text { ungual phalanx } \\
\text { (hoof) }\end{array}$ & right temple & \multicolumn{2}{|c|}{ underbelly, on the left side } \\
\hline $\begin{array}{l}\text { Part of the } \\
\text { anatomy }\end{array}$ & muscle & \multicolumn{2}{|c|}{ vein on muscle } & horn & vein & \multicolumn{2}{|c|}{$\begin{array}{l}\text { nerves on the yellowish part of the } \\
\text { abdomen }\end{array}$} \\
\hline Colour & red & red & blue & black & dark blue & yellow & white \\
\hline Number of layers & 12 & 5 & 7 & 6 & 13 & 3 & 11 \\
\hline $\begin{array}{l}\text { Ground } \\
\text { (number of layers) }\end{array}$ & $\begin{array}{l}\text { lead white } \\
\text { (1) }\end{array}$ & $\begin{array}{c}\text { lead white } \\
\text { (2) }\end{array}$ & $\begin{array}{l}\text { lead white } \\
\text { (1) }\end{array}$ & - & $\begin{array}{l}\text { lead white } \\
\text { (2) }\end{array}$ & $\begin{array}{l}\text { lead white } \\
\text { (1) }\end{array}$ & $\begin{array}{l}\text { lead white } \\
\text { (1) }\end{array}$ \\
\hline Red & $\begin{array}{l}\text { mercury sulphide } \\
\text { red lead? } \\
\text { (red lake) } \\
\text { (iron oxide) }\end{array}$ & $\begin{array}{l}\text { mercury sulphide } \\
\text { red lead? } \\
\text { (red lake) }\end{array}$ & & mercury sulphide & red lead & - & - \\
\hline Yellow & chrome yellow & chrome yellow & - & chrome yellow & - & lead oxide & - \\
\hline Blue & - & - & Prussian blue & - & Prussian blue & - & - \\
\hline White & - & - & lead white & - & lead white & lead white & $\begin{array}{c}\text { lead white } \\
\text { (calcium carbonate) } \\
\text { barium sulphate }\end{array}$ \\
\hline $\begin{array}{l}\text { Black } \\
\text { Coating }\end{array}$ & - & - & - & carbon black & carbon black & - & - \\
\hline (number of layers) & (1) & - & (1) & (1) & (1) & - & (1) \\
\hline
\end{tabular}

The pigments listed were found mixed in one or more layers of the cross-sections; the pigments in brackets are minor ones.
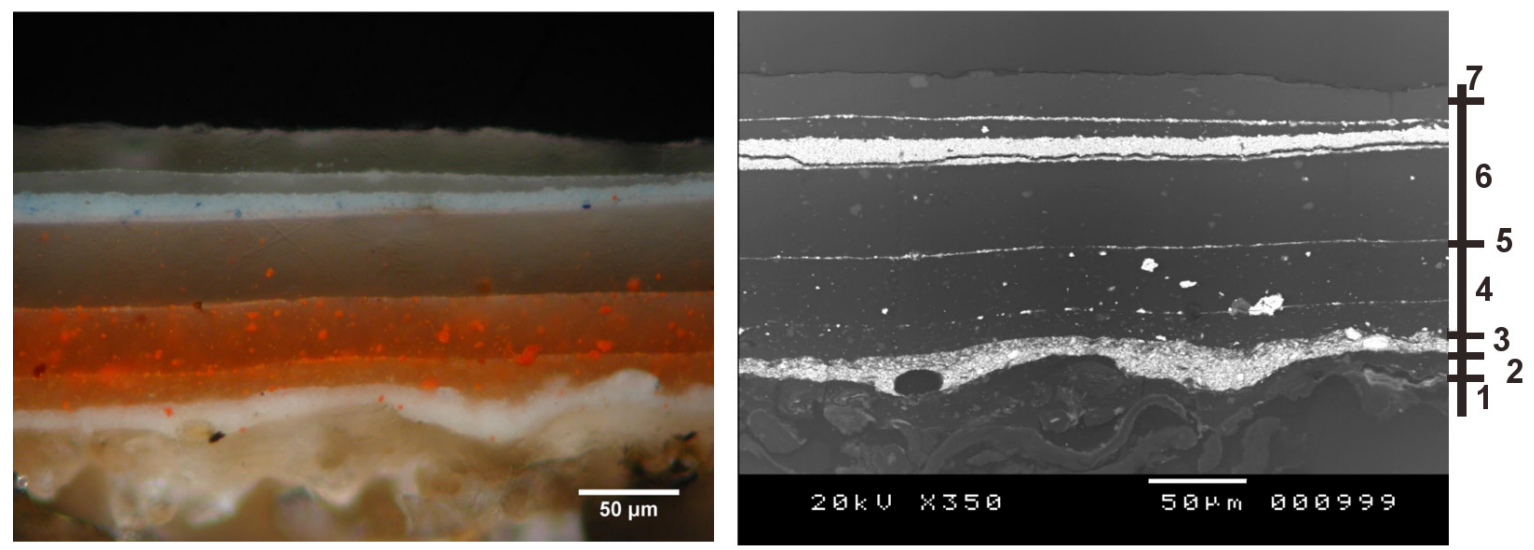

Figure 9 Cross-section of the sample AUZ-02, red polychromy: (a) optical microscopy, polarized light image; and (b) back-scattered electron image (1: rapapillotage paper, 2: organic underlayer, 3: ground (2 layers), 4: red polychromy (3 layers), 5: ground, 6: blue polychromy (5 layers), 7: coating). (C) Inp / M.-C. Papillon.

A small range of pigments was used to produce the different colours of the polychromy. In general, two or three pigments were mixed together in the layers in different ratios, which yielded different shades of colour. For example, the red mercury sulphide, which was a quite expensive pigment, is widely used in the red colours and is mixed with chrome yellow, possibly red lead and very small amounts of a red lake, thus providing a bright red colour. Mercury sulphide is also mixed with chrome yellow and carbon black in the hoof. The particle size of the more or less spherical mercuric sulphide is medium (diameter, 1-3 $\mu \mathrm{m}$ ). The yellowish part of the abdomen is made of lead oxide, which renders a pale cooler shade. Prussian blue is mixed 
either with carbon black to obtain dark blue veins, or with lead white for a lighter blue; it is used alone in glazed layers. All these pigments are customary pigments widely used through time for all types of painted works (works of art, and decorative or common objects). In contrast, chrome yellow should be pointed out because its introduction was the most recent at the date of the creation of the object: lead chromates were first used in France as a pigment in wallpaper (1818) and to print on textiles (1820) [14]. The particles observed in the layers of the samples have an acicular shape (monoclinic form) and medium size (1-2 $\mu \mathrm{m}$ long). The identification of very sparse deep red particles (two or three only in each layer) was unsuccessful by EDX analysis; alumina was detected as the main element, with tin as a secondary element. A Raman spectroscopic analysis (analytical details are in the Appendix) provided the spectrum of an anthraquinonic compound [15], possibly carminic acid. It is known that some recipes advise using tin salt for carmine lake preparation [14, 16, 17]. Small amounts of calcium carbonate are detected as an extender in the upper glazed layers of the sample AUZ-05 (nerves) but it seems to be an impurity in the ground. The barium sulphate (baryte or blanc fixe) found in one of the white layers (AUZ-05, upper layers) mixed with lead white $(1: 1)$ is interpreted as an extender [14, 18]. Last, a small amount of the element nitrogen is found in most of the layers (organic underlayer, ground, glazed layers and coating) which is interpreted as a marker of the binding material glue.

In conclusion, the painting technique revealed by the microscopic study shows great concordance between the information already known and the observations made previously in this study, and by Nijhoff Asser [5]. The chosen pigments and the painting technique were combined to provide deeply translucent colour rendering. The painting technique appears both simple - one binder, small range of pigments - and complex because of the great number of superimposed layers and the mixing of pigments. The mastering of this technique by Auzoux probably explains the very high quality of the models, the admiration of his colleagues and his commercial success.

\section{UNDERSTANDING THE SURFACE DAMAGE USING MOCK-UP SAMPLES}

\section{Materials and methods}

Flaking of the polychrome surface is a type of degradation frequently encountered on Auzoux models. As reported by Nijhoff Asser [5], 40 Auzoux models out of 73 belonging to the Museum Boerhaave, Leiden (NL) showed extensive flaking. After exploring the material composition of the horse model and examining the damages, it seemed rather likely that the cracks and flakes in the paint layers had been caused by repeated temperature and humidity variations. Indeed, the room where the object was stored at the National School of Agronomy in Grignon lacked maintenance for decades and had been flooded several times.

Mock-up samples were prepared to reproduce the painted support and were artificially aged using cycling heat and humidity conditions. A climatic chamber Vötsch VC0020 was used at the Centre de recherche sur la conservation des collections (CRCC, Paris). Cycles of 11 hours at $40^{\circ} \mathrm{C}$ and $85 \%$ relative humidity (RH), representing extreme summer climate conditions, alternating with $25^{\circ} \mathrm{C}$ and $30 \% \mathrm{RH}$, representing indoor winter conditions, were used.

A paper-based support was used for the mock-up to reproduce the carton collé. It was made of Whatman ${ }^{\circledR}$ No. 1 paper $\left(88 \mathrm{~g} \mathrm{~m}^{-2}\right)$, an industrially made cotton fibre cellulose paper which is not sized. Two types of starch were applied to impregnate the paper: Zin Shofu ${ }^{\circledR}$, a pure wheat starch glue (Atlantis, France), and a commercial food grade organic wheat flour. Historic sources mention that both types of glue could have been used by cartonniers (papier mâché craftmen) [19].

The glues were prepared by mixing $11 \mathrm{~g}$ of starch powder and $100 \mathrm{~g}$ of deionized water, and were cooked in a domestic-type sauce-maker. The two glues formed a gel with similar consistency but different colour. The starch glue was white whereas the flour glue was beige.

The paper was sized with a brush and the sheets of sized paper were ripped in small pieces intended to imitate the papier collés pieces. Four layers of paper strips were applied onto each other while still wet. On the surface, a layer of paper (also Whatman No. 1) was applied to mimic the rapapillotage paper. The machine direction of this layer of paper was recorded. Industrially made papers typically react differently to hygrothermal variations in the machine direction and in the cross direction, the former being the preferred orientation of the fibres along their length. The swelling of the fibres thus yields a larger dimensional change in the cross direction. Five of these 'unpainted' samples $(15 \mathrm{~cm} \times$ $8 \mathrm{~cm}$ ) of each type were made. Measurements of the weight, size and thickness of the samples were done after several cycles of accelerated ageing.

In parallel, painted samples were prepared using two types of supports: papier collé made with the same recipe 
as for the unpainted samples previously described, and glass, which was chosen for its inertness to hygrothermal changes. These samples were intended to observe how the painted layer evolves upon ageing when applied on a hygroscopic support and a non-hygroscopic one. For these painted samples, only starch glue was used as its properties were best characterized.

Three different gelatines were chosen as binding media for the painted layers: a type B photographic grade bovine gelatine (Rousselot $\left.{ }^{\circledR} 125 \mathrm{LH}\right)$, a type A pharmaceutical grade fish gelatine (HMV Norland ${ }^{\circledR}$ ) and sturgeon gelatine prepared in the laboratory with sturgeon bladder (Salianski Kremer Pigmente ${ }^{\circledR}$ Isinglass glue purchased from Laverdure, France). The types A and B refer to the production method of the gelatine by partial hydrolysis of collagen, either in alkaline (type B) or in acid medium (type A). Gelatine from bovine origin is alkali produced (type B) and acid-treated gelatine (type A) is from porcine or fish origin. Depending on the origin of the protein there are some differences in the physical properties and in the amino acid content [20].

Several tests were made to define the concentration of gelatine that would allow thick layers of paint to be obtained. The glue had to be viscous enough to allow a thick coating and to avoid dripping, but fluid enough to permit easy painting of small details. The bovine gelatine could not be used at room temperature and was applied warm [21]. The following concentrations were chosen for similar viscosity at room temperature: bovine gelatine 15\% (wt:wt), fish gelatine 20\% (wt:wt) and sturgeon glue $10 \%$ (wt:wt). Both supports were previously covered with a white ground layer made of lead white pigment $50 \%$ (wt:wt) with each corresponding binding. Then, for each gelatine type, series with three pigmented layers and series with ten pigmented layers were made on both types of support in order to evaluate the role of the thickness of the paint layer in the flaking process. Vermilion red was added to the gelatines at a concentration of $2 \%$ (wt:wt) to better visualize the damages.

\section{Results}

The main modifications observed on the unpainted samples were visual and tactile. The samples made with wheat flour glue became more yellow and rough to the touch with ageing time. The samples made with starch glue remained supple but underwent more deformation with ageing time.

Cracks appeared on all the painted samples with ten paint layers made on glass support after three days of accelerated ageing. After six days of accelerated ageing, only the series painted with sturgeon glue showed

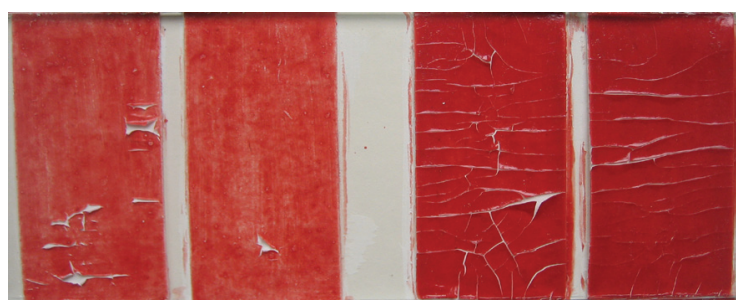

'Figure 10 Photograph of the mock-ups of Carton collé (paper-based support) painted using sturgeon glue as binding media after 21 days of accelerated ageing: (left) three layers of pigmented glue on a lead whitebased ground layer; and (right) ten layers of pigmented glue on a lead white-based ground layer. (C) Inp / B. Dumont.

flaking for both the samples with three and ten layers of pigmented glue.

Among the samples made on paper support, only those painted with sturgeon glue showed changes (Figure 10). The first cracks appeared after six days of accelerated ageing, along the direction of the paper fibre length, i.e. the machine direction. The cracks resulted from the tension created by the larger expansion of the fibres in diameter rather than in length.

From these observations it was concluded that the support played a major role in the flaking process. The appearance and the pattern of the cracks were very similar to those observed in some of the flaking areas on the surface of the horse model (Figure 11). It was thus concluded that the paper used for the horse was most likely an industrially made paper as it seemed to react to humidity differently in the two directions. Moreover, sturgeon gelatine seemed to be more brittle as a binding medium than fish and bovine gelatines, especially when RH reached $70 \%$.

The conclusions of the accelerated ageing tests of the mock-ups under cycling heat and humidity conditions led to the interpretation that the poor physical condition of the paint layers of the horse was a result of temperature and humidity variations in the storage room where the object had spent several years. Therefore, considering the variety of materials involved in the manufacturing of the horse, the optimal climatic conditions for its storage should be a temperature in the range of $15^{\circ} \mathrm{C}$ to $20^{\circ} \mathrm{C}$ and stable $\mathrm{RH}$ around $50 \%$.

\section{CONSERVATION STATE AND SURFACE TREATMENT}

In the field of heritage preservation, study collections (i.e. collections used for teaching and research purposes) and heritage collections (i.e. collections that have no 
function other than that related to museography) have clearly defined and different purposes. It is interesting to note that during the course of its existence the horse evolved from the former category to the latter, as it first served as an anatomical model before falling out of use, when it became a scientific heritage object. The conservation work carried out on the object was entirely dependent upon this fact.

\section{Structural damage and paint flaking}

The first examination was performed on the closed horse. Opening it was awkward due to the severe structural imbalance, which made the horse visibly lean slightly towards its left side. Later, a safe way to open the object was ensured by releasing the hinges located at the back under the tail and allowing the upper part to be carried on a prepared support. Then the examination of the interior parts could be made. They were found to be in an excellent state of preservation.

However, two of the exterior parts were distorted. The superficial back muscle no longer fit perfectly in its original position. The upper part of the left thoracic limb also had suffered from distortions, which was evidence of past manipulations of the object. As a result, it could no longer be attached to the withers.

The entire surface was soiled and covered with dust. Very thick paint flakes were observed. A pattern of cracks was visible extending over the whole exterior surface with flaking and cup lifting that varied from mild to severe (Figure 11). In these areas, all the paint layers had lifted off the paper surface and the rapapillotage paper was delaminated. On numerous small areas, the painted layers were partially or completely missing. Because of this poor surface condition, not only could the model hardly be moved and handled, but also the polychromy was illegible as the details of the sophisticated painting could no longer be appreciated. However, the surfaces of the interior parts of the horse were still in very good condition and showed the quality of the original painting. As mentioned above, knowing of the poor storage conditions of the horse and from the results obtained with accelerated ageing of the mock-ups, it was assumed that the flaking of the paint had probably been caused by the climate changes and by the loss of flexibility of the paint binding media due to ageing.

\section{Conservation treatment}

Unfortunately, the main structural distortions could not be treated because this type of alteration is not reversible.

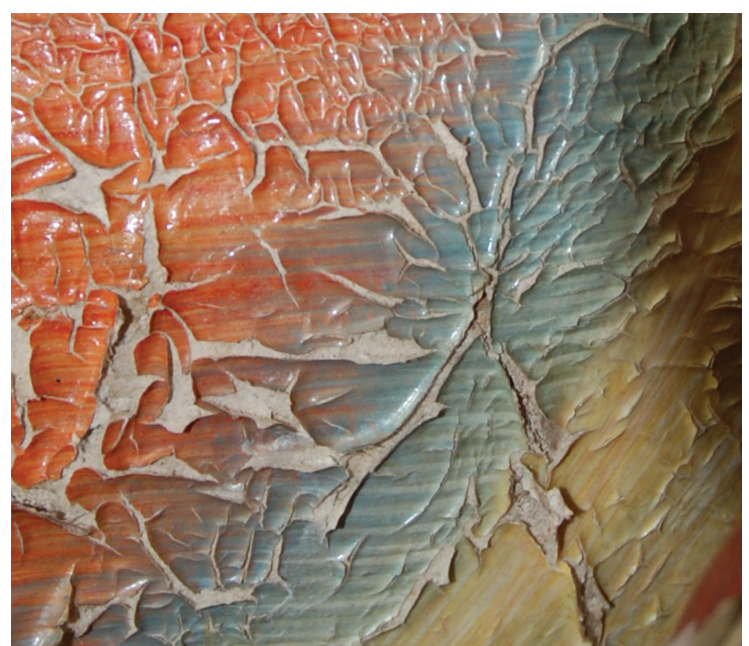

Figure 11 Photograph of a detail of the horse's abdomen showing the flaking pattern (image width $=8 \mathrm{~cm}$ ). $\odot$ Inp / B. Dumont.

To prevent any further damage, it was decided that in the future the horse should be displayed closed. The main conservation treatment on the horse model involved cleaning and flattening the paint layers and the surface coating layer.

In order to consolidate the flakes, which appeared to be hard and distorted, it was necessary to loosen and soften the material. Because of the nature of the materials, the most effective solvent was deemed to be water. However, at room temperature, water caused swelling of the painted surface, and further damage due to softening of the surface coating was anticipated. The use of ice-cold water, as reported by Barden [7], was attempted and proved to be effective by limiting the swelling process and allowing the surfaces to be cleaned. Nevertheless, in the parts where the soiling was heavy, this cleaning process was not sufficient. Artificial saliva, Mucin from porcine stomach M1778 $\left(\right.$ Sigma $\left.^{\mathbb{R}}\right)$, diluted in deionized water $0.2 \%$ (wt/wt), was then used.

After cleaning, the problem of flaking paint was addressed and the surface consolidation was carried out. After wetting the surface it appeared easier and more appropriate to apply an aqueous-based adhesive. The properties required for an adhesive were that it should be compatible with the polychromy, have a good anchorage allowing adhesion of paper on paper and be simple to use. The presence of metallic elements also had to be taken into consideration.

Preliminary tests were done on an area where it was possible to apply heavy weight with lead bags. A first 
trial with ice-cold water only was made in the hope that the adhesive present would be reactivated. This proved unsuccessful. The flakes could be flattened but the adhesion was insufficient. Four adhesives were then chosen for testing. In addition to the two gelatines used previously to prepare the mock-ups (sturgeon glue and type B bovine Rousselot $125 \mathrm{LH}$ ), a type A porcine gelatine (Sigma-Aldrich ${ }^{\circledR}$ Gelatine porcine skin, G1890) and an aqueous dispersion of acrylic resin (Primal 330S ${ }^{\circledR}$ ) were used. All adhesives were prepared at a concentration of first 3\% then 5\% (wt:wt). The sturgeon glue and the acrylic dispersion were used at room temperature, while the gelatines $\mathrm{A}$ and $\mathrm{B}$ were used warm $\left(30-35^{\circ} \mathrm{C}\right)$. The gelatines, which are of mammalian origin and cannot be used at room temperature, had to be fluid enough to easily wet and penetrate the substrate before drying, but not too warm, as high temperature could be harmful for the paint layers, and denature the protein.

Sturgeon glue is less viscous than a type B gelatine at equivalent concentration and temperature [22], which made it necessary to apply weight for 12 to 24 hours during drying to obtain good adhesion. The use of sturgeon glue was thus excluded since, due to the three-dimensionality of the horse body, using weights was impossible in most instances. The acrylic resin gave disappointing results; because of its low viscosity it penetrated through the paper layers and could not provide adhesion. Moreover, it could not relax the mostlifted flakes very efficiently. The gelatines A and B were the most effective to consolidate and relax the lifted and flaking paint. They provided a good mechanical anchorage upon gelation. Moreover, they penetrated less deeply into the surface layers, thus avoiding wetting the superficial and internal metal elements.

Unfortunately, with the bovine gelatine it was also necessary to apply weight during the first hours of drying. Although it took less time than with sturgeon glue, the process of applying weights to the threedimensional object was awkward and difficult for a conservator working alone. The type A porcine gelatine at a concentration of $5 \%$ (wt:wt) provided the best option. This gelatine has a high Bloom gel strength (Bloom index of 300), a strong adhesive power and a very light colour compared to the other tested gelatines. These properties allowed working on all the reliefs without the need for weights. Moreover, once dry, a flexible and translucent surface film was obtained.

The porcine gelatine was applied with a small brush under the flakes to allow the adhesion between the flake and the paper support, and then slightly onto the flake itself to consolidate the pigmented layers. The flaked surface was then covered with a polyester film, Bondina ${ }^{\circledR}$, and rubbed down with the thumb until good mechanical anchorage occurred. The process could last 15 to 20 minutes and the average size of the areas treated at one time was $8 \mathrm{~cm} \times 5 \mathrm{~cm}$. Because the polychromy was flaking to various degrees and in various shapes, and the flakes reacted differently to moisture, it was necessary to slightly modify the conservation treatment in different areas. According to Nijhoff Asser [5], re-adhering flakes depends mainly on their size and thickness and on the split interface. In this study, some flakes were so hard that the relaxation of the paint layer took longer. In other situations the paint layers would split during the treatment, which would cause irreversible damage of the polychromy. Sometimes the surface was soiled to such an extent that the cleaning took twice as long as the stabilization of the flakes. The polyester film was removed after 24 hours and the excess gelatine was cleaned with artificial saliva (Figures 12a and 12b). The result of the treatment on the appearance of the horse was very satisfying as the reliefs and the details of the painting appeared visible again (Figure 13).

\section{CONCLUSION}

Working on the Auzoux horse model was an interdisciplinary experience that required the expertise of conservators, curators and scientists. Through scientific examination, it was possible to precisely document and better understand both the technique of the creator and the materials he used. The work reported here should be helpful to conservators, art historians and scientists who will have to work on Auzoux models in the future. In particular, the study of the paint layers provided an understanding of the complex painting process and documented the variety of pigments used by Dr Auzoux around 1850. The materials research has revealed clearly that storing or exhibiting the models opened or dismantled can cause irreversible distortions. This is the case for large models such as the horse, but also applies to smaller Auzoux creations such as snails, silk moths or dogfish.

Throughout this research, flaking paint surfaces were found to be a common deterioration of these anatomical models. The experiments that were carried out showed the high sensitivity of the painted surface to temperature and humidity changes, due to the hygroscopic nature of the paper used as support. This study showed the importance of maintaining optimal and stable climatic conditions for the storage of these models.

On the horse, the lifting of all the paint layers caused the paper support to extensively delaminate. 

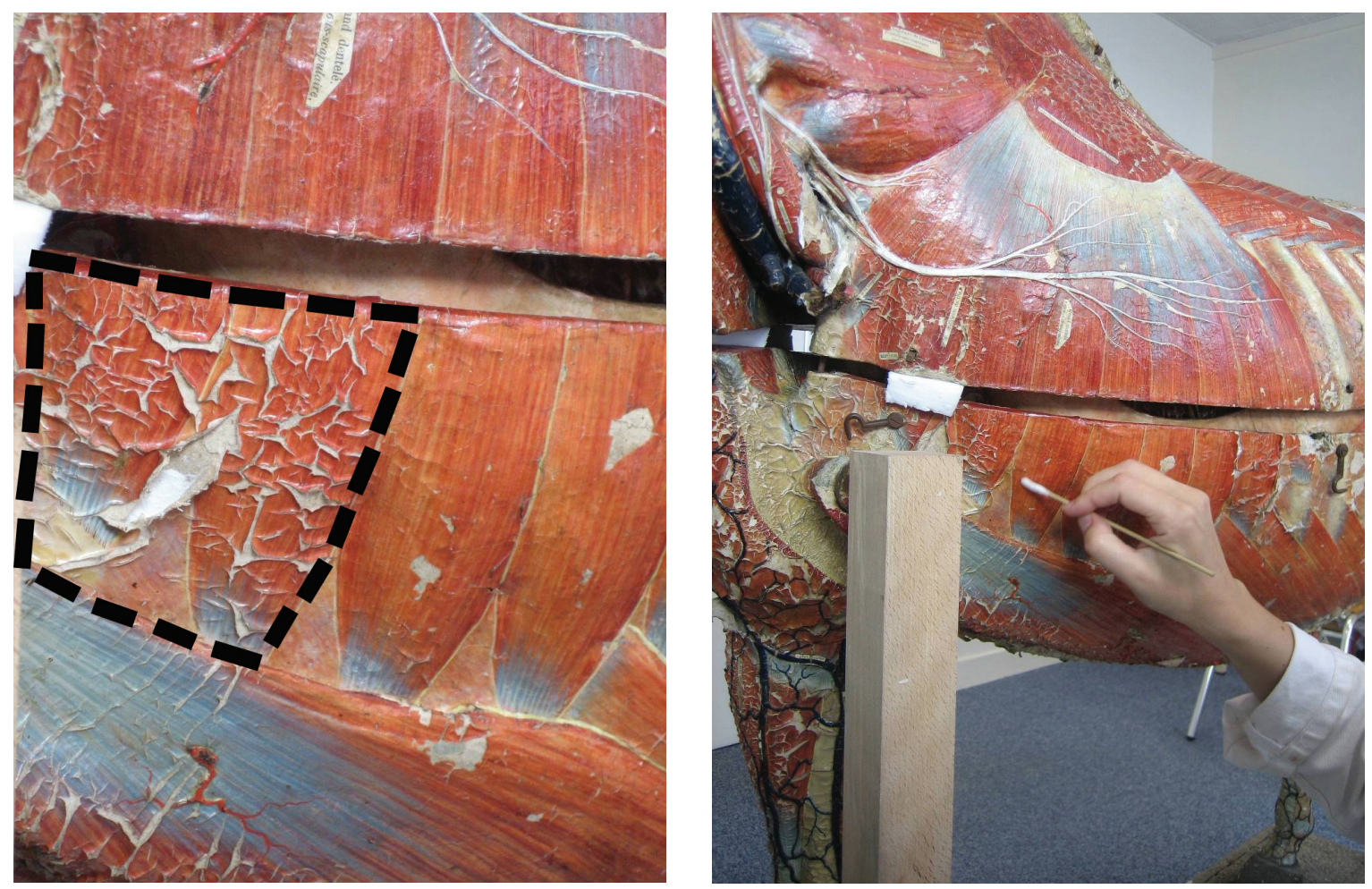

Figure 12 Photographs showing the ongoing treatment on the rib cage area: (a) before treatment; and (b) while removing the excess adhesive with artificial saliva. @ Inp / B. Dumont.

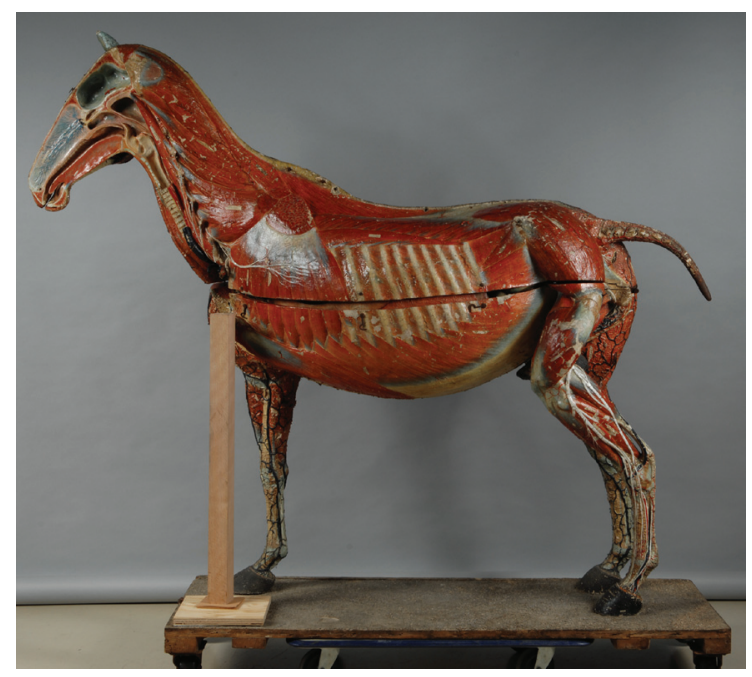

Figure 13 Photograph of the left lateral view of the horse after surface treatment. () Inp / G. Vanneste.
The adhesive chosen, a gelatine of porcine origin with adequate adhesive power and a high gel strength, allowed a good relaxation and re-adhesion of the paint flakes to the paper, without having to resort to the application of weight. The conservation treatment, despite having been extremely time consuming, had highly satisfying results as it revived the beauty and the legibility of the object. This treatment and the technical study of the specific surface damage, including the research into an appropriate adhesive, can inform the surface consolidation of smaller Auzoux models which are more frequent in collections than are the larger models. With the renewed interest in these models due to their recently recognized status as part of our scientific heritage, artefacts of this type are likely to be found in conservation laboratories more often. Today this beautiful anatomical model is displayed in the Musée Fragonard as a testimony of veterinary science heritage. 


\section{APPENDIX: ANALYTICAL METHODS}

\section{GC and GC-MS analyses for organic compounds identification}

GC-MS analyses, carried out at the Laboratoire de Dynamique, Interaction et Réactivité (LADIR, UMR 7075 CNRS and UMPC-Université Pierre et Marie Curie Paris 6), were achieved with a Varian Saturn 2000 ion trap device linked to a Varian 3800 gas chromatograph. The mass spectra were recorded in the electron ionization mode at $70 \mathrm{eV}$, in full scan mode from $\mathrm{m} / \mathrm{z} 40$ to 650 . The temperature settings were the following: ion trap at $200^{\circ} \mathrm{C}$, manifold at $50^{\circ} \mathrm{C}$ and transfer line at $300^{\circ} \mathrm{C}$.

The sample preparation for polysaccharides analysis was as follows. Samples from the protective coating on the surface of the object and from the red paint layer directly underwent methanolysis with acetyl chloride in methanol $(1 / 25, \mathrm{vol} / \mathrm{vol})$ followed by silylation using Sylon ${ }^{\mathrm{TM}}$ HTP (Sigma). The water extracts from carton pate samples for the identification of the binding media underwent previous filtration on $0.22 \mathrm{~mm}$ pores PVDF filters and evaporation to dryness before the methanolysis.

The sample preparation for protein analysis included complete acid hydrolysis in $\mathrm{HCl} 6 \mathrm{M}$ during 24 hours at $110^{\circ} \mathrm{C}$, followed by neutralization and derivatization with ethyl chloroformate. For the sample of protective coating on the surface of the object this could be done directly on the dry sample. In the case of the water extracts from carton pâte samples, filtration and evaporation to dryness were carried out beforehand as described above. The sample preparation for the identification of molecular markers of oil, wax and natural resins was carried out by adding boron trifluoride-methanol complex (20\%, $\mathrm{vol} / \mathrm{vol}$ ) directly to the red paint layer sample in order to achieve transmethylation. The organic phase obtained after the solvent extraction in hexane was analysed.

The gas chromatography was carried out at the Institut national du patrimoine (Inp) on a Perichrom PR2100 equipped with a flame ionization detection (FID) and a Varian Factor FourVF-5ms capillary column (15 m length, $0.15 \mathrm{~mm}$ i.d., $0.15 \mu \mathrm{m}$ film thickness). The molecular constituents were eluted using splitless mode (injector at $300^{\circ} \mathrm{C}$ ) and helium as carrier gas at a constant flow of $1 \mathrm{~mL}$ per minute with the following temperature programme of the oven: $50^{\circ} \mathrm{C}$ for 0.5 minute, $50-100^{\circ} \mathrm{C}$ at $45^{\circ} \mathrm{C}$ per minute, $100^{\circ} \mathrm{C}$ for 1 minute, $100-300^{\circ} \mathrm{C}$ at $30^{\circ} \mathrm{C}$ per minute, $300^{\circ} \mathrm{C}$ for 10 minutes. The temperature of the FID detector was fixed at $310^{\circ} \mathrm{C}$ with $12 \mathrm{~mA}$ gain.

\section{Optical Microscopy and SEM-EDX}

The optical microscopy was carried out at the Inp using a Nikon Eclipse ME600 microscope with devices for polarized light microscopy (PLM) and epifluorescence microscopy (EFM), equipped with a mercury-vapour lamp and two filter cubes (emission wavelengths $\geq 420 \mathrm{~nm}$ and $\geq 520 \mathrm{~nm}$ ).

The scanning electron microscopy and a combined $\mathrm{X}$-ray microanalysis were carried out at the CRCC. A variable pressure scanning electron microscope (VPSEM) JEOL JSM-5410LV was used to examine the samples. The accelerating voltage was $20 \mathrm{kV}$ and the pressure was $12 \mathrm{~Pa}$ high. Samples were observed using back-scattered electron imaging (BEI), which is used to underline the relative mean atomic number of the components within the samples. The inorganic compounds, extenders and pigments, were identified by energy dispersive X-ray spectrometry (EDX) by means of an Oxford Instruments Link PentaFET Si(Li) detector and the software ISIS Link. The EDX operating conditions were as follows: accelerating voltage $20 \mathrm{kV}$, ATM windows, take-off angle $30^{\circ}$, working distance (WD) $20 \mathrm{~mm}$, count time $80 \mathrm{~s}$, approximate dead time $30 \%$. The samples were carbon coated before analysis.

\section{Raman Spectroscopy}

The analysis by Raman spectroscopy was carried at the LADIR with a Horiba Jobin-Yvon HR800 dispersive Raman spectrometer equipped with edge filters and using the 458 or $514 \mathrm{~nm}$ excitation wavelengths of an air-cooled $\mathrm{Ar}^{+}$laser. Laser power at sample was settled at $30 \mu \mathrm{W}$ in order to preserve sample integrity. Sample visualization and Raman scattering collection is performed through a reverse microscope notably equipped with a $100 \times$ objective which allows a spatial resolution close to $1 \mu \mathrm{m}$. A motorized microscope stage allows the sample displacement. The grating at 600 grooves $\mathrm{mm}^{-1}$ used gives a spectral resolution of about $3 \mathrm{~cm}^{-1}$ in the $1000 \mathrm{~cm}^{-1}$ region for the signal recorded with an air-cooled CCD detector. Spectra are typically recorded for 10 to $300 \mathrm{~s}$ and their interpretations are performed using laboratory databases.

\section{ACKNOWLEDGEMENTS}

This work is part of the Master's degree thesis of the first author at the Institut national du patrimoine (Inp, Paris). The authors wish to thank J. Levy, sculpture conservator currently teaching at the Inp, and C. 
Degueurce, curator at the museum of the national veterinary school of Maisons-Alfort (Musée Fragonard), who tutored the first author for the conservation treatment. The authors are grateful to J. Barthez of Centre de recherche sur la conservation des collections (CRCC, Paris) for the paper fibres analyses, to Dr Ludovic Bellot-Gurlet of Laboratoire de Dynamique, Interaction et Réactivité (LADIR, UMR 7075 CNRS and UMPC-Université Pierre et Marie Curie Paris 6) for the Raman spectroscopy analyses, and to G. Vanneste of Inp for his photographs and X-radiographs. They are also grateful to E. Nijhoof Asser, paper conservator in private practice in Amsterdam, for very helpful advice during the conservation treatment. F. Dubosc and B. Barral from Musée de l'écorché du Neubourg are also acknowledged for helpful discussions.

\section{REFERENCES}

1 Grob, B.W.J., The World of Auzoux: Models of Man and Beast in Papier-mâché, Museum Boerhaave, Leiden (2000).

2 Davis, A.B., 'Louis Thomas Jérôme Auzoux and the papier mâché anatomical model', in La Ceroplastica nella Scienza e Nell'Arte, Florence, 3-7 June 1975, Rivista di Storia delle Scienze Mediche e Naturali 20 (1975) 257-278.

3 Auzoux, L.T.J., Tableau synoptique, Cheval clastique, Auzoux, Paris (1855).

4 Pain, D., L'anatomie clastique: Une affaire normande au XIXè siècle, doctoral thesis, University of Caen (1981).

5 Nijhoff Asser, E., Reissland, B., Grob, B.W.J., and Goetz, E., 'Lost fingers, scurfy skin and corroding veins: Conservation of anatomical papier-mâché models by Dr Auzoux', in ICOM Committee for Conservation, 15th Triennial Meeting, New Delhi, 22-26 September 2008: Preprints, Vol. I, ed. J. Bridgland, Allied Publishers Pvt, New Delhi (2008) 285-292.

6 Lebrun, M., and Magnier, M., Nouveau manuel complet du mouleur en plâtre, au ciment, à l'argile, à la cire, à la gélatine [...], Leonce Laget, Paris (1978).

7 Barden, C., 'Conservation treatment: Anatomical model of a man', Smithsonian National Museum of American History, Behring Center (1999), http://americanhistory.si.edu/ anatomy/preservation/nma03_preser_ct_1.html (accessed 28 November 2010).

8 Karlson, O., 'Ein pappmaché-pferd aus Halle', Restauro 2 (1998) 102-107.

9 Aitken, Y., Cadel, F., and Voillot, C., Constituants fibreux des pâtes papiers et cartons: Pratique de l'analyse, 1ere édition, Centre Technique du Papier et Ecole Française de Papeterie et des Industries Graphiques, Grenoble (1988).

10 Malpeyre, M., Nouveau manuel de la fabrication des colles végétales, animales et composées, Roret, Paris (1876).

11 Lebrun, M., Nouveau manuel complet du cartonnier, du cartier, et du fabricant de cartonnages, ou l'art de faire toutes sortes de cartons, de cartonnages et de cartes à jouer, Roret, Paris (1845) 69.
12 Colinart, S., 'Matériaux constitutifs', in Sculptures en cire de l'ancienne Égypte à l'art abstrait, ed. J-R. Gaborit and J. Ligot, Réunion des musées nationaux, Paris (1987) 29-57.

13 Murrel, V.J., 'Some aspects of the conservation of wax models', Studies in Conservation 16 (1971) 95-109.

14 Perego, F. (ed.), Dictionnaire des matériaux des peintres, Belin, Paris (2005).

15 Echard, J.P., Bertrand, L., von Bohlen, A., Le Hô, A-S., Paris, C., Bellot-Gurlet, L., Soulier, B., Lattuati-Derieux, A., Thao, S., Robinet, L., Lavédrine, B., and Vaiedelich, S., 'Nature of the extraordinary finish of Stradivari's instruments', Angewandte Chemie International Edition 49 (2010) 197-201.

16 Kirby, J., Spring, M., and Higgit, C., 'The technology of eighteen- and nineteenth-century red lake pigments', National Gallery Technical Bulletin 28 (2005) 69-95.

17 Schweppe, H., and Roosen-Runge, H., 'Carmine', in Artists' Pigments: A Handbook for their History and Characteristic, Vol. 1, ed. R.L. Feller, University Press and National Gallery of Art, Cambridge and Washington (1986) 47-64.

18 Feller, R.L., 'Barium sulfate - natural and synthetic', in Artists' Pigments: A Handbook for their History and Characteristic, Vol. 1, ed. R.L. Feller, University Press and National Gallery of Art, Cambridge and Washington (1986) 255-285.

19 Petit, G., Nouveau manuel complet du cartonnier, Roret, Paris (1903) 95.

20 Rose, P.I., The Theory of the Photographic Process, 4th edn, McMillan, New York (1977) 51-67.

21 Schellmann, N.,'Animal glues: A review of their key properties relevant to conservation', Reviews in Conservation 8 (2007) 55-66.

22 Nguyen, T., 'Gelatin as adhesive', Papier Restaurierung 4 (2005) 31-34.

\section{AUTHORS}

Barbara Dumont received her Master's degree in aesthetics and art sciences from the University of Paris I Panthéon-Sorbonne, France in 1999. She graduated from the Institut national du patrimoine (Inp, Paris), France in 2008 as an objects conservator. Her Master's degree dissertation was dedicated to the technical and historical study as well as conservation work on an Auzoux horse model. She is currently working as a private conservator. Address: 26 rue d'Avron, 75020 Paris, France.Email:dumontbarbara@hotmail.com

Anne-Laurence Dupont graduated from the University of Montpellier, France in 1988 with a MSc in biochemistry. She then completed a MSc in art conservation at the University of Paris-La Sorbonne in 1994, specializing in paper conservation. She was a Charles E. Culpeper fellow in Conservation Science at the National Gallery of Art, Washington, DC, USA from 1998 to 2001. She received her PhD in chemistry 
from the University of Amsterdam, The Netherlands in 2003. She joined the Centre de recherche sur la conservation des collections (CRCC) Paris, France in 2001 as conservation scientist. Her research focuses on the characterization of the degradation of cellulose and paper, the impact of the environment on cellulosic artefacts and the development of novel methods for paper stabilization. Address: Centre de recherche sur la conservation des collections, Muséum national d'histoire naturelle, 36 rue Geoffroy-Saint-Hilaire, 75005 Paris, France. Email:aldupont@mnhn.fr

Marie-Christine Papillon received her PhD in scanning electron microscopy and X-ray microanalysis from the University of Paris XII-Créteil, France. She was integrated as a conservation scientist into the French Ministry of Culture in 1998. She worked from 1991 to 1995 at the laboratory of the Institut francais de restauration des œuvres d'art (IFROA), France. Since 1996, she has been the head of the scientific laboratory of the Institut national du patrimoine (Inp,
Paris). She is in charge of the scientific investigation of the materials of works of art and has special interests in paintings technology and paintings materials and in conservation studies. She takes part in the pedagogy of the department and the training. She is involved in European standardization works in the field of cultural heritage. Address: Institut national du patrimoine, département des restaurateurs, 150 avenue du Président Wilson, F-93210 Saint-Denis-La Plaine, France. Email: marie-christine.papillon@inp.fr

Gä̈L-François JeAnNel received his Master's degree in analytical chemistry at the University of Rennes 1, France. His Master's degree in chemistry of flavours and fragrances from the University of Le Havre, France, gave him a second specialization. Since 2006 he has worked at the Institut national du patrimoine (Inp, Paris) as a chemical engineer and is in charge of the analysis of organic materials on works of art by GC-MS (gas chromatography-mass spectrometry) and infrared spectroscopy. Address: as Papillon.Email:gael-francois.jeannel@inp.fr

Résumé - L'article rend compte des investigations techniques et des travaux de conservation entrepris sur un modèle anatomique de cheval en papier mâché créé au milieu du XIXe siècle par le Dr Auzoux. L'objet souffrait d'un déséquilibre structurel dû à une distorsion de la structure métallique interne, et sa surface peinte montrait des écaillages sérieux. Les principaux traitements réalisés sont un nettoyage de la surface et une consolidation des couches picturales. Une gélatine à fort pouvoir adhésif et à grade résistance au cisaillement a été choisie comme consolidant. La méthode mise en cuvre s'est révélée très efficace et devrait pouvoir être appliquée dans le futur à d'autres modèles d'Auzoux détériorés. Afin de mieux comprendre le processus d'écaillage, des maquettes de surfaces peintes ont été réalisées et soumises à un vieillissement artificiel avec des cycles de chaleur et d'humidité. Ce travail expérimental a montré l'importance du maintien d'un climat stable et optimal pour le stockage du modèle. Un examen scientifique des techniques et des matériaux mis en ceuvre dans la fabrication du cheval a été mené en utilisant les sources historiques ainsi que l'investigation analytique. Les résultats ont confirmé les précédentes données publiées à propos des modèles d'Auzoux. Ils ont également révélé des informations complémentaires encore non publiées à ce jour, car ce type de recherche n'avait encore jamais été mené sur un Modèle d'Auzoux de grande taille

Zusammenfassung - In dieser Arbeit werden technische Untersuchungen und Konservierungsarbeiten eines von Dr. Auzoux aus papier mâché geschaffenen, anatomischen Modells eines Pferdes aus der Mitte des 19. Jahrhunderts beschrieben. Das Objekt litt unter strukturellem Ungleichgewicht auf Grund von Verformungen der inneren Metallstruktur und die Fassung wies schwere Abblätterungs-Erscheinungenen auf. Die Behandlung bestand im Wesentlichen aus der Reinigung der Oberflächen und der Konsolidierung der Malschichten. Als Konsolidierungsmittel wurde eine Gelatine mit guter Klebkraft und hoher Gelstärke gewählt. Die entwickelte Methode erwies sich als sehr effektiv und könnte in Zukunft auch bei anderen Modellen von Auzoux angewendet werden. Um den Prozess der Abblätterung der Malschichten besser verstehen zu können, wurden Modelle der bemalten Oberflächen hergestellt und unter zyklischer Veränderung von Temperatur und Feuchtigkeit künstlich gealtert. Das Experiment belegte die Wichtigkeit der Gewährleistung optimaler und stabiler klimatischer Bedingungen bei der Aufbewahrung des Modells. Die wissenschaftliche Untersuchung der zur Herstellung des Pferdes verwendeten Techniken und Materialien wurde unter Beizug von Quellenschriften als auch mit dem Einsatz analytischer Untersuchungen durchgeführt. Die Ergebnisse bestätigten früher für Auzoux-Modelle publizierte Daten. Darüber hinaus konnten weitere bisher nicht bekannte Informationen gewonnen werden, da eine derartige Untersuchung eines so großen Auzoux-Modells noch nie durchgeführt worden war. 
Resumen - Este artículo documenta las investigaciones técnicas y el trabajo de conservación llevado a cabo en un modelo anatómico de papier mache de un caballo, realizado a mediados del siglo XIX por el Dr. Auzoux. El objeto sufrió un desequilibrio estructural debido a la deformación de la estructura metálica interior; su superficie pintada mostraba además unas graves descamaciones. Los tratamientos incluían principalmente la limpieza de la superficie y su consolidación y asentado. Como consolidante se escogió una gelatina con buen poder adhesivo y alta consistencia en gel. El método desarrollado se mostró muy efectivo y podría ser aplicado en el futuro a otros modelos Auzoux. Con el fin de conocer mejor el proceso de descamación se elaboraron muestras pintadas que fueron envejecidas artificialmente mediante ciclos de humedad y temperatura. Este trabajo experimental puso de manifiesto la importancia de mantener condiciones climáticas óptimas y estables para el almacenamiento del objeto. El examen científico de las técnicas y materiales empleados en la fabricación del caballo se relacionaron con las fuentes históricas, así como en investigaciones analíticas. Los hallazgos confirmaron los datos previamente publicados sobre los modelos Auzoux. Se desvela además información adicional no documentada ya que hasta ahora ninguna investigación de este tipo se ha realizado en una obra de tan grandes dimensiones. 